\title{
Research Knowledge Utilization on Integrated Municipal Solid-Waste Management and Community Participation for Public Policy in the Deep South of Thailand
}

\author{
Sawpheeyah Nima * \\ Health System Management Institute, \\ Prince of Songkla University, \\ Hat Yai, Songkhla, Thailand \\ Ilfarn Tolaema \\ Thai Islamic Medical Association (TIMA), \\ Yala, Thailand
}

\author{
Pitchaya Nualdaisri \\ Faculty of Pharmaceutical Sciences, \\ Prince of Songkla University, \\ Hat Yai, Songkhla, Thailand \\ Pongthep Sutheravut \\ Health System Management Institute, \\ Prince of Songkla University, \\ Hat Yai, Songkhla, Thailand
}

\begin{abstract}
Knowledge translation for research utilization is an important process for community to learn and properly use of research findings such as decision making based on evidence. However, a large gap exists between research production and practice. Few studies have conducted the research utilization in public policy for community waste management solutions. The objectives of the study were to describe the knowledge from research, the gap between knowledge and practice, translation to communities, and policy recommendations for strategies to improve the use of evidence in community waste management problems. This study is participatory action research based on Innovation diffusion theory initiating to solve community waste problem in real situation by community participation targeting residents living in 3 provinces in the Deep South of Thailand. The pre-selection of 4 communities was carried out in November 2017- December 2018, based on waste problem concerns. Data were collected by public meeting and community forum and field observation and then were analyzed by content analysis. The study was conducted in five stages were: (1) knowledge findings from research were discussed within communities providing a unique synthesis of evidence, (2) persuasion to communities to implementation including public policy, (3) community decision for proper solutions, (4) implementation in each community, and (5) confirmation and evaluation. The research utilization for public policy in community waste management, could be practiced in a long period. This can be suggested that developing an integrated strategy should also draw paradigms from the socio-economic context of this area.
\end{abstract}

Keywords: Research knowledge utilization, municipal solid-waste management, community participation, public policy

Received: 12 December 2018; Accepted: 16 January 2019; Published: 19 February 2019

\section{INTRODUCTION}

Research Utilization (RU) refers to the implementation of evidence into practice. It has a critical role in community strategies to promote the adoption of innovations and solution for several problems. The nature of this knowledge extends well beyond a population level by Knowledge Translation (KT) and Technology Transfer (TT). The former

\footnotetext{
${ }^{*}$ Correspondence concerning this article should be addressed to Sawpheeyah Nima, Health System Management Institute, Prince of Songkla University, Hat Yai, Songkhla, Thailand E-mail: sawpheeyah.n@psu.ac.th
}

(c) 2019 The Author(s). Published by KKG Publications. This is an Open Access article distributed under a Creative Commons Attribution-NonCommercial-NoDerivatives 4.0 International License. 
is designed to communicate the value of conceptual knowledge in research findings, while the latter is a process of transforming an idea from theory and practice in research for the novel application of a technology into a viable product. Research findings are also being used increasingly in worldwide in enhancing the effectiveness of health (Alshehhi, 2016; Jarjusey, 2017; Kelly, Wicker, \& Martin, 2016). However, Evidence-Based Practice (EBP) and knowledge translation gaps are widespread across community health and environmental management.

Participatory Public Policy (PPP) acts a mechanism not only for seeking to increase the effectiveness and quality of policymaking by involving citizens in policy but also operation at local levels of governance or practitioners to scale up to higher tiers of central government (Bua \& Escobar, 2018; Endang \& Risal, 2017). Over decades, there has been a shift from a top-down governance to a more horizontal governance. In Thailand, many local governments make public policy in a participatory way with community stakeholders such as public organizations, civil society actors, civilians and other interested parties. It is a process which provides private individuals an opportunity to influence public decisions. The reason behind both community engagement and participation is that communities should have some powers over the decisions that affect their lives. In addition, communities can be enhanced the effectiveness of KT and TT activities by researchers, scholars in academic institutes and universities (Giuri, Munari, Scandura, \& Toschi, 2019; Pranee \& Papapankaid, 2017). This process also needs to strengthen the relationships with education institutions and public authorities (Da Silva \& Bolson, 2018).

Solid Waste Management (SWM) remains a challenge everywhere in worldwide. It is the one thing just about every city government provides for its residents. This can be integrated with environmental solutions that requires supporting public policies to make it practical, especially in less developed countries (Ayuningrat, Noermijati., \& Hadiwidjojo, 2016; Chalhoub, 2018). As it is an indicator for sustainable development, many countries have formulated a policy on SWM (Ikhlayel, 2018). Participatory public policy becomes an interesting tool to deal with SWM. PPP usually partner with their customers and communities to manage and reduce waste from collection to disposal while recovering valuable resources and creating clean such a renewable energy (Siu \& Xiao, 2017). Due to an increasing attention which is now paid to sustainable waste management resulting from the increasing disposal cost as well as the growing public appreciation on environmental and health impacts, PPP is then essential to play the role in SWM in communities. The final goals of all kinds of processing wastes is that it can then be reused in producing different low carbon footprint products in order to develop sustainable actions (Xuan, Poon, \& Zheng, 2018).

Nowadays, Municipal Solid Waste (MSW) generation rates are rising in Thailand due to rapid population growth and urbanization. The local government has a responsibility to undertake policy procedures that protect its citizens from the dangers of pollution of the environment. Although, managing waste properly is essential for big cities, the lack of understanding affect the different stages from its inception to its final disposal. The process of treating solid wastes and offers a variety of solutions for recycling items are that they don't need to belong to trash anymore. However, common mistakes in community waste management are occur during handling, storage, and transportation resulting in various pollutions and health risk due to uncontrolled waste disposal, open dumping, and open burning (Bhawal Mukherji, Sekiyama, Mino, \& Chaturvedi, 2016). On the other hands, there are several studies that effort to present various modeling of municipal solid waste management for construction and demolition in global (Wu, Zuo, Zillante, Wang, \& Yuan, 2019). The emerging of "Zero waste" in 1990 for waste handling, emphasizes planning for the elimination of waste rather than managing waste (or no waste to manage). An attempt has been made to introduce this concept to practice. For example, 3Rs: reduce, reuse and recycle are usually introduced for the nonbiodegradable waste fractions. In contrast, a significant gap still exists between the various research evidences and what is occurring in community practice for waste management.

Currently, the Deep South of Thailand-Pattani, Yala and Narathiwas province, several municipalities are also facing both large quantities of waste that has been overloading their capacity for elimination due to lack of sanitation systems as well as a shortage of land for disposing of waste. The waste management activities in these provinces are mainly affected by the rising of a consumer society; lack of data to plan the system; lack of knowledge about waste characteristics; non-defined policy for the sector; lack of regulation about the matter; low socio-economic living conditions of the population; and uncorrected method to dispose of solid waste within their communities. According to these situations, communities have concerned about the waste crisis in country and the urgent need for change. Improving MSW is one of the most effective ways to strengthen community. Furthermore, an analysis framework that explains how the social members adopt the new innovative ideas and how they made the decision towards it. As adoption of a new idea or new knowledge does not happen simultaneously in a social system, this needs an effort and 
specific method to do for effective outcomes and impacts. One of popular theory framework that seeks to explain how, why, and at what rate new ideas and technology spread within community is Diffusion of Innovations (DOI) that developed by (Kim, Lee, \& Contractor, 2019; Rogers, 1976). DOI theory has been applied in different fields to understand how people use a new knowledge to their applications.

To date, KT and TT to improve the municipal solid waste management system with PPP is still limited in Thailand. Since the research question of this study is that how to improve knowledge utilization in municipal solid-waste management through KT and TT with participatory public policy, this article is aiming to present the key element stages for the best performance of MSW management model in the Deep South of Thailand with an applying of DOI to describe why people adopt new ideas and technologies through a participatory research approach.

\section{Conceptual Framework}

The theoretical framework in the participatory research approach that seeks to describe the dynamic process of the implementation of KU through KT and TT with PPP is the DOI Theory developed by Rogers (1976) in 5 established adopter categories as follows (Rogers, 1976):

\begin{tabular}{|c|c|c|}
\hline $\begin{array}{l}\text { Dependent Variables: } \\
\text { 1. Social- ecological context in } \\
\text { Deep South, Thailand: } \\
\text { - Pattani Province } \\
\text { - } \text { Yala Province } \\
\text { 2. Key components ofDOI: } \\
\text { - The innovation: KU, KT and } \\
\text { TT } \\
\text { - The adopter: Researchers, } \\
\text { Community Leaders and } \\
\text { Civil Society Actors } \\
\text { - The social system: Structure } \\
\text { and Community Readiness } \\
\text { - The individual adoption- } \\
\text { process: awareness, } \\
\text { persuasion, decision, } \\
\text { implementation, and } \\
\text { continuation } \\
\text { The diffusion system: } \\
\text { Community Communication } \\
\text { and PPP }\end{array}$ & $\begin{array}{l}\text { Five Stages of the } \\
\text { Adoption Process: } \\
\text { (1) Knowledge Discussion } \\
\text { about Research Findings } \\
\text { (to exposure to the new } \\
\text { idea) } \\
\text { (2) Persu asion } \\
\text { (to deal with attitude } \\
\text { towards the new idea) } \\
\text { (3) Community Decision } \\
\text { (choice to accept or reject } \\
\text { a new idea) } \\
\text { (4) Implementation } \\
\text { (to bring the new idea to a } \\
\text { trial) } \\
\text { (5) Confirmation and } \\
\text { Evalu ation } \\
\text { (to continue using the new } \\
\text { idea and develop an } \\
\text { innovation) }\end{array}$ & $\begin{array}{c}\text { Independent } \\
\text { Variables: } \\
\text { Model of } \\
\text { Knowledge } \\
\text { Utilization in } \\
\text { MSW } \\
\text { Management } \\
\text { through KT and } \\
\text { TT with PPP in } \\
\text { the Deep South } \\
\text { of Thailand }\end{array}$ \\
\hline
\end{tabular}

Figure 1 Innovation diffusion theory framework in participatory action research for initiating to solve MSW in the deep south of Thailand

\section{METHODOLOGY}

\section{Design}

This study was a Participatory Action Research (PAR) a collaborative approach, in which researchers and communities were involved in all aspects of a research study. It was carried out in November 2017- December 2018 based on innovation diffusion theory initiating to solve community waste problem in real situation by community participation.

\section{Setting Site and Paticipants}

The study was carried out in the 3 provinces in the Deep South of Thailand. The pre-selection of 4 communities which was chosen by purposive sampling based on community waste problem concerns as follows:

1) Pattani Province: Lampho and Yamu Sub-district, Yaring District. 
2) Yala Province: Raman District.

3) Narathiwas Province: Kok-Kian Subdistrict, Muang District.

The adoption of community engagement facilitates meaningful contribution to the design and implementation of

PAR. All researchers were designed to work in partnership with informal settlement communities to define a problem, design a solution, and implement change. Consequently, encouraging stakeholder participation and involving key local organizations may guide the effective development of the study protocols. In this project, local-residents, recyclers, property management officers and cleaners in 4 communities were recruited to voice their views on public policy design for SWM. All stakeholders were included both individuals and groups that have an interest or roles in waste management.

\section{Data Collection}

Data were collected by the semi-structured interviews in community meeting, focus group discussion, and participatory observation in the public forum and community workshops. The tape-recorded interviews were used in all sessions. The other methods were mapping, modelling and environmental observation. Fieldnotes were written by note-takers and moderators summarized all key points in each issue.

\section{Data Analysis}

All interviews were transcribed verbatim and analyzed using qualitative content analysis to identify main themes.

\section{Ethics Consideration}

The Human Ethical Review Board at Health System Management Institute, Prince of Songkla University approved the study (ref. no. 2018/016). All participants received written and oral information about the study, and informed consent was obtained. Participation was strictly voluntary, and all participants were informed that they could withdraw from the study at any time without having to give an explanation.

\section{RESULTS}

\section{Socio-Economic Considerations and Demographic Data}

The socio-economic context related to household waste utilization and MSW management of 3 provinces in Deep South of Thailand was described below.

1) Urbanization and lifestyle changes are now becoming a general phenomenon transformed from rural to semi-urban community in Deep South of Thailand. It has created a lot of waste problems in modern societies.

2) Increasing number of people or high rate of population growth is being concerned to generate waste in this area due to the consequent change in amount of household consumption. The per capita waste generation rates obtained are generally estimate $1.0 \mathrm{~kg} / \mathrm{cap} /$ day.

3) Household size and income were involved in willingness to separate the waste in many ways. For example, poor people live in a dense community that they have no time to concern about an environment rather than their daily earning to survive. The participants in this study were characterizes in Table 1.

Table 1 THE DEMOGRAPHIC DATA OF STUDY PARTICIPANTS $(N=257)$

\begin{tabular}{ll}
\hline Types of Participants & Number of Participants \\
\hline Local-Residents and Youths & 139 \\
Community Leaders/Religious Leaders & 48 \\
Management Officers & 12 \\
Cleaners/Recyclers & 10 \\
Local Governors & 8 \\
Health Professional and Village Volunteers & 12 \\
Market and Resort Entrepreneurs & 28 \\
\hline
\end{tabular}

\section{The Gap between Research Knowledge and Practice on MSW Management in Community}

Data in this step was presented by participants in each meeting. Building the MSW management model through KT and TT with PPP using a PAR Approach in Figur 2. All 4 communities were realized that their environment and health resulted from the impact of improper waste management. The community leaders revealed that knowledge, attitudes, 
and practices on MSW management among members were quite poor. This brought them to promote environmental awareness inside their communities. All members knew the meaning of waste was that unwanted things, residues discarded, and no longer required by the initial user. For this reason, when they created waste and threw it away into landfills. MSW is a crucial service provided by local government in Thailand, but it is often inefficient and underperforming in many cities in the Deep South of Thailand. Since local citizen didn't know how to increase the value of MSW management, the research findings for MSW management were needed for implementation in among these communities. Key research findings and recommendations were then listed in following items:

1. Waste generation source, storage and family disposal practices in communities.

2. Solid Waste collection process in communities.

3. Waste separation and recycling

After that, the research findings for MSW management were discussed to apply for this study setting. This was the priority for them to deal with MSW management because managing solid waste well and affordably was one of the key challenges and one of the key responsibilities of a local government in Thailand.

\section{The MSW Management Procedures}

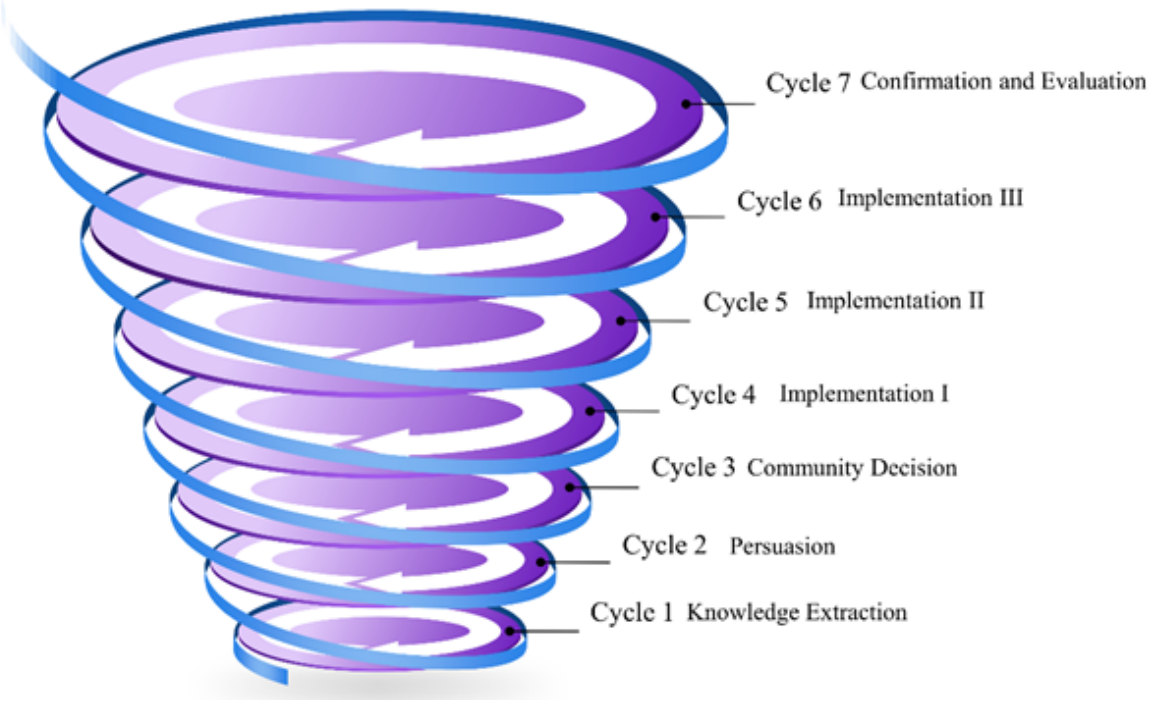

Figure 2 Building the MSW management model through KT and TT with PPP using a participatory action research approach

The study was conducted in five stages based on DOI theoretical framework and result findings were revealed as follows:

Knowledge extraction: According from community reflexed for MSW management, it appeared to be both inadequate knowledge and inappropriate method. Furthermore, Knowledge from research findings were then discussed within communities providing a unique synthesis of evidence. In this stage, community resident showed their willingness to engage in waste management by seeking knowledge. Their knowledge, attitude, and practices played a crucial role as their view point which is extremely vital in providing solutions to future environmental and problems related MSW management. The additional topics were discussed such as waste generation rate of municipal solid waste in their communities, waste composition (organic, paper, plastic, glass, metal, and other), sources and types of waste, and waste management practices. This step brought them to realize that MSW management should be started at the household level, and it was not difficult for communities to achieve.

Communities gave information about the sources and types of waste generated that can be divided into 3 categories as shown in Table 2. 
Table 2 SOURCES AND TYPES OF WASTE GENERATED IN ALL 4 COMMUNITIES

\begin{tabular}{lll}
\hline Sources & Generators & Types of Solid Wastes \\
\hline Household and Residential & Single and multifamily dwellings & $\begin{array}{l}\text { Cardboard, food wastes, paper, plastics, textiles, } \\
\text { leather, yard wastes, wood, glass, metals, and } \\
\text { ashes }\end{array}$ \\
Institutional & Schools, hospitals, government buildings & $\begin{array}{l}\text { Paper, plastics, wood, food wastes, glass, and } \\
\text { metals }\end{array}$ \\
Commercial & $\begin{array}{l}\text { Stores, resort-hotels, restaurants, markets, and } \\
\text { office buildings }\end{array}$ & $\begin{array}{l}\text { Paper, plastics, wood, food wastes, glass, and } \\
\text { metals }\end{array}$ \\
Municipal Services & Street cleaning, landscaping, parks, and beaches & Street sweepings; landscape and tree \\
\hline
\end{tabular}

In this process, communities learned to separate their waste in household such as kitchen and garden waste, papers, plastic, glass, textiles, and chemical waste into each container. The waste was divided into a bio-degradable waste and non-bio degradable waste, so that it was easier for them to handle it later. First, the waste segregation was started to the separation of wet waste and dry waste, the purpose was to recycle dry waste easily and to used wet waste as compost in each community. In addition, communities knew that segregation was important for environmental and health impacts in many ways. For example, the dangers of toxic chemical substances can be leakage into ground water and methane (a green-house gas) production in landfills due to inappropriate waste segregation. When members segregated waste, there was reduction of waste that reaches landfills and occupies space in their communities.

Persuasion: According to above results shown that everyone cannot stop waste production entirely. In order to save money, energy, and natural resources, the persuasion was then discussed in steps of MSW management in waste reduction inside their communities. This step, the brain storming technique helped them to identify the typed of waste, the sources of waste, volume of waste generated and advantages to use 3Rs technique in waste management. All reducing waste methods are demonstrated in Table 3.

All 4 communities were persuaded to SWM implementation including public policy. This activity consisted of a basic practice that were source reduction, collection, recycling, composting, and landfilling/dumping. In this stage, communities were introduced the correct method of waste collection which referred to the collection of solid waste from the point of production (e.g., residential, industrial commercial, institutional) to the point of treatment or disposal. After MSW was segregation in each source of waste generation, MSW was collected by two means:

1) House-to-house method: Waste collectors visited each individual house to collect garbage. The users generally had to pay a fee monthly for the service.

2) Community bins: Users brought their garbage to community bins that were placed at fixed points in a community. MSW was then picked up by the municipality.

Table 3 THE REDUCING WASTE METHODS AND 3RS PROMOTIONS PROVIDED BY 4 COMMUNITIES

\begin{tabular}{|c|c|c|}
\hline Step & $\begin{array}{l}\text { Three R's of Sustain- } \\
\text { ability }\end{array}$ & Brainstorming Ideas in Reducing Wastes \\
\hline \multirow[t]{2}{*}{1} & $\begin{array}{l}\text { Reduce-To decrease } \\
\text { the amount of waste. }\end{array}$ & 1. Make less waste (consume less) in homes and stop to thrown away so much stuff into a bin. \\
\hline & & $\begin{array}{l}\text { 2. Try to use reusable bags while shopping. } \\
\text { 3. Bring our own cloth bags and stop using plastic bags. } \\
\text { 4. Stop using disposable paper plates/dishes/spoons. } \\
\text { 5. Stop buying plastic water bottles. } \\
\text { 6. Take our lunch box to work in reusable containers. } \\
\text { 7. Buy in bulk or larger containers. } \\
\text { 8. Take along a reusable coffee cup instead of disposable coffee cups. }\end{array}$ \\
\hline \multirow[t]{2}{*}{2} & $\begin{array}{l}\text { Reuse-To bring things } \\
\text { back to use again. }\end{array}$ & 1. Try to make efforts to reuse household items in several ways. \\
\hline & & $\begin{array}{l}\text { 2. Learn to repair something broken (such as our cloth) rather than discard or throw it away to purchase } \\
\text { a new one. } \\
\text { 3. Donate things or give to someone else instead of throwing them away that we might not use anymore } \\
\text { such as old electrical equipment, clothes and books. } \\
\text { 4. Turn used paper into art supplies and reuse old plastic bags for several times. }\end{array}$ \\
\hline
\end{tabular}


Table 3. CONTINUE...

5. Many items found around the homes or simple household things that can be used again for different purposes such as glass jars and pots, gallon jugs, newspaper, old tires, and used wood.

3 Recycle and Compost1. Start to recycle household rubbish and unwanted items.

ing-To turn and use material in another form.

2. To deal with our food waste into a compost or worm farm.

Community decision for proper solutions with PPP: Decision-makers guided members to MSW Management relying on research findings and well known for research utilization. The component goals of decision making consisted of 3 elements that were: (1) to serve public health by maintaining healthy conditions in communities; (2) to protect environment for sustainability and green society; and (3) to keep resources by effective using. For these reasons, the participatory public policy (PPP) was also used as a tool in developing the decision-making goals that assisted to achieve accountability, transparency and active citizenship. This initiating participatory approaches occupied to policy-making or bottom-up through stakeholder groups that have a role in making decisions on policy, project design and implementation of MSW management in communities. This step was illustrated in Figure 3.

Table 4 FINDINGS FROM 5 STAGES BASED ON DOI THEORETICAL FRAMEWORK

\begin{tabular}{ll}
\hline Stages & Outcomes \\
\hline (1) Knowledge Extraction & IMSWM Knowledge Body \\
(2) Persuasion & IMSWM Guideline \\
(3) Community Decision with PPP & IMSWM Strategy \\
(4) Implementation & Engagement of Strategy in the entire community \\
(5) Confirmation and Evaluation & 1. Community lesson learn and sharing in their best practice or innovative approaches. \\
& 2. Announcement and promote this program \\
\hline
\end{tabular}

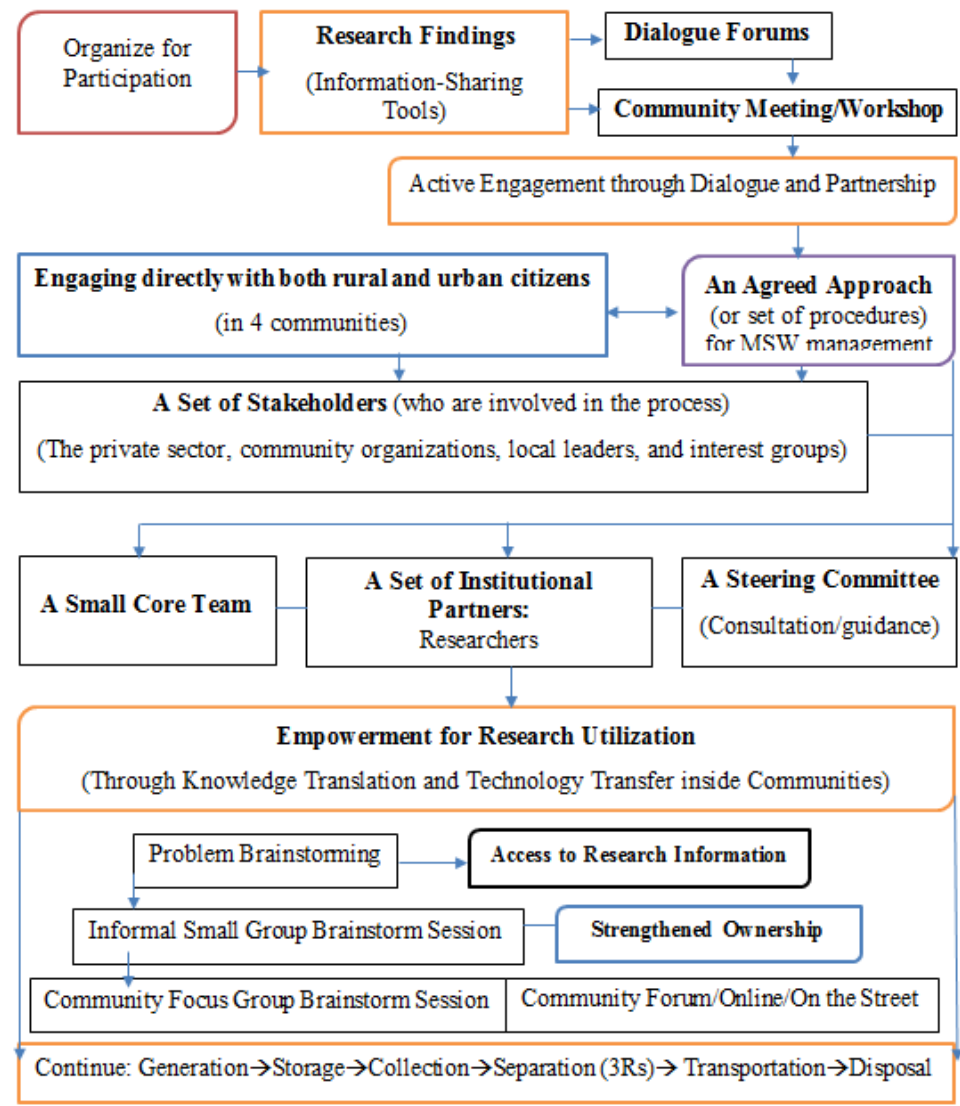

Figure 3 The community decision process for proper solutions with PPP 
Implementation in each community: The implementation of a new IMSWM strategy derived from the participatory public policy was engaged in the entire community. An agreed approach was assisted by the steering committee. The community members were informed and educated in MSW management from research findings with the well-structured public relations and implementation strategy.

Confirmation and evaluation: Successful waste and recycling systems were dependent on relationships and partnerships among community members. All stakeholders played their part as environmental sustainability issues increasingly seek stronger community support and action to reach their goals. In this study, public awareness is a key to successful waste management in all communities. Residence owners are responsible by community rules. After communities have a waste policy, this helped them understand why they need to sort waste before discard. The local government workers also were trained to determine the kinds of waste to elimination. An IMSW management strategy not only improve health problems including disease related to waste accumulation such as dengue disease but also significantly create pleasant living environment. In addition, it protected waste management workers from related occupational safety. IMSWM was then called as a resource management instead of waste management in those communities.

\section{DISCUSSION AND IMPLICATIONS}

This study was focused on municipal solid waste management resulting of the preparation of a community strategy to promote their citizen awareness about recycling and selective collection of solid waste before discard. After implementing rules and regulations for MSW management, it represented that the persuade of the 3R scheme (reduce, reuse and recycle) was satisfied by all participants. Activities were performed to the control of generation, storage, collection, transfer, and transport, treatment and processing, and disposal of solid wastes in participated communities. The success factors in MSW management in this study were local community citizens which have willing to separate waste in their homes with a huge potential for uptake of recycled products. Other factors were community leaders driven by a structured public policy that they tried to monitor and continuing evaluation. The training program related to $3 \mathrm{R}$ s strategic approach was also well accepted to community awareness in MSW management.

\section{CONCLUSION}

There were at least 3 factors that played vital role in increasing efficiency of municipal waste management in this study. The special legal participatory public policies and strategies were driven by community leaders and local citizens to archive this MSW management. However, attitude and perception relying socio-economic context towards waste management are critical factors to predict in explaining intention or behavior for sustainable MSW management in Thailand.

\section{ACKNOWLEDGEMENT}

All authors wish to express the gratitude to Health System Management Institute (HSMI), Research and Development Office (RDO), Prince of Songkla University and National Research Council of Thailand (NRCT) for the research support. Deep appreciation is extended to all individuals, companies and organizations cited in this article.

\section{REFERENCES}

Alshehhi, A. S. (2016). Organizational knowledge systems. International Journal of Business and Administrative Studies, 2(6), 193-200. doi:https://doi.org/10.20469/ijbas.2.10004-6

Ayuningrat, M. P., Noermijati., \& Hadiwidjojo, D. (2016). Green product innovation's effect on firm performance of managerial environmental concern and green communication. Journal of Administrative and Business Studies, 2(2), 56-63. doi:https://doi.org/10.20474/jabs-2.2.1

Bhawal Mukherji, S., Sekiyama, M., Mino, T., \& Chaturvedi, B. (2016). Resident knowledge and willingness to engage in waste management in Delhi, India. Sustainability, 8(10), 1065-1070. doi:https://doi.org/10.3390/su8101065

Bua, A., \& Escobar, O. (2018). Participatory-deliberative processes and public policy agendas: Lessons for policy and practice. Policy Design and Practice, 1(2), 126-140. doi:https://doi.org/10.1080/25741292.2018.1469242

Chalhoub, M. S. (2018). Public policy and technology choices for municipal solid waste management a recent case in Lebanon. Cogent Environmental Science, 4(1), 152-160. doi:https://doi.org/10.1080/23311843.2018.1529853

Da Silva, C., \& Bolson, C. (2018). Public policy for solid waste and the organization of waste pickers: Potentials and limitations to promote social inclusion in Brazil. Recycling, 3(3), 40-50. doi:https://doi.org/10.3390/ 
recycling 3030040

Endang, K., \& Risal. (2017). The effect of investment decision financing decision dividend payment policy and company size. Journal of Administrative and Business Studies, 3(2), 105-113. doi:https://doi.org/10.20474/jabs-3.2.5

Giuri, P., Munari, F., Scandura, A., \& Toschi, L. (2019). The strategic orientation of universities in knowledge transfer activities. Technological Forecasting and Social Change, 138, 261-278. doi:https://doi.org/10.1016/ j.techfore.2018.09.030

Ikhlayel, M. (2018). Indicators for establishing and assessing waste management systems in developing countries: A holistic approach to sustainability and business opportunities. Business Strategy \& Development, 1(1), 31-42. doi:https://doi.org/10.1002/bsd2.7

Jarjusey, F. (2017). Consumers' awareness and knowledge about food waste in Selangor, Malaysia. International Journal of Business and Economic Affairs, 2(2), 91-97. doi:https://doi.org/10.24088/ijbea-2017-22002

Kelly, L. A., Wicker, T. L., \& Martin, D. M. (2016). Utilizing research findings: Nurse leaders and researchers working together. Nurse Leader, 14(5), 350-353. doi:https://doi.org/10.1016/j.mnl.2016.04.004

Kim, M. J., Lee, C. K., \& Contractor, N. S. (2019). Seniors' usage of mobile social network sites: Applying theories of innovation diffusion and uses and gratifications. Computers in Human Behavior, 90(7), 60-73. doi:https://doi.org/10.1016/j.chb.2018.08.046

Pranee, S., \& Papapankaid, C. (2017). Factors affecting purchasing decision of community products in Ranong province. International Journal of Business and Administrative Studies, 3(2), 79-83. doi:https://doi.org/ 10.20469/ijbas.3.10005-2

Rogers, E. M. (1976). New product adoption and diffusion. Journal of Consumer Research, 2(4), 290-301. doi:https:// doi.org/10.1086/208642

Siu, K. W. M., \& Xiao, J. X. (2017). Public facility design for sustainability: Participatory action research on household recycling in Hong Kong. Action Research, 14(6), 54-60. doi:https://doi.org/10.1177/1476750317698027

Wu, H., Zuo, J., Zillante, G., Wang, J., \& Yuan, H. (2019). Construction and demolition waste research: A bibliometric analysis. Architectural Science Review, 1(6), 1-12. doi:https://doi.org/10.1080/00038628.2018.1564646

Xuan, D., Poon, C. S., \& Zheng, W. (2018). Management and sustainable utilization of processing wastes from ready-mixed concrete plants in construction: A review. Resources, Conservation and Recycling, 136(3), 238-247. doi:https://doi.org/10.1016/j.resconrec.2018.04.007 